\title{
Mycoplasma agalactiae and the Mycoplasma mycoides cluster in goat herds in the states of Pernambuco and Paraíba, Brazil
}

\section{Mycoplasma agalactiae e Mycoplasma mycoides cluster em rebanhos caprinos nos estados de Pernambuco e Paraíba, Brasil}

\author{
Luciana Florêncio Vilaça Lopes ${ }^{1}$; Elizabete Cristina da Silva ${ }^{2}$; Anidene Christina \\ Alves de Moraes ${ }^{1}$; Elizabete Rodrigues da Silva ${ }^{3 *}$; Kleber Régis Santoro ${ }^{3}$; Ângela \\ Maria Vieira Batista ${ }^{4}$; Severino Benone Paes Barbosa ${ }^{4}$
}

\begin{abstract}
The objective of this study was to detect Mycoplasma agalactiae (Ma) and the Mycoplasma mycoides cluster $\left(\mathrm{Mm}_{\text {cluster }}\right)$ in 373 goat milk samples of different breeds from herds located in Pernambuco and Paraíba states, as well as to evaluate somatic cell count (SCC) and milk composition from positive animals. For this, DNA extraction from milk samples was carried out, followed by generic and speciesspecific amplification by Polymerase Chain Reaction (PCR). Milk constituents were determined by medium infrared spectrometry and SCC by flow cytometry. Analyses of variance and tests of comparison of means verified the effects of positivity on the evaluated characteristics. The frequencies for $\mathrm{Ma}$ and $\mathrm{Mm}_{\text {cluster }}$ were 43.21 and 5.70\%, respectively. In all genetic groups, Ma was detected in all positive samples, whereas $\mathrm{Mm}_{\text {cluster }}$ was only observed in samples from Moxotó, Parda Sertaneja, and that without a defined racial pattern. Statistical difference was observed $(p<0.05)$ between mean values of protein, casein and SCC in positive and negative Ma samples. In terms of $\mathrm{Mm}_{\text {cluster }}$ there was only a statistically significant difference in the SCC parameter. The detection of Mycoplasma in samples of goat milk suggests an introduction of infected animals into the evaluated herds, as well as possible contact with the etiological agents at fairs and exhibitions.
\end{abstract}

Key words: Contagious agalactiae. Dairy goats. Mycoplasmosis.

\section{Resumo}

O presente trabalho teve como objetivo detectar Mycoplasma agalactiae (Ma) e Mycoplasma mycoides cluster $\left(\mathrm{Mm}_{\text {cluster }}\right)$ em 373 amostras de leite caprino de diferentes raças, pertencentes a rebanhos localizados nos estados de Pernambuco e Paraíba, bem como avaliar a composição e a contagem de células somáticas (CCS) de leite de animais positivos para aqueles agentes. Para isso realizou-se a extração de DNA de amostras de leite, seguida de amplificação genérica e espécie-específica por Reação em Cadeia da Polimerase (PCR). Os constituintes do leite foram determinados por espectrômetro de infravermelho médio e a CCS, por citometria de fluxo. As análises de variância e testes de comparação de médias verificaram os efeitos da positividade sobre as características avaliadas. As frequências para

\footnotetext{
${ }^{1}$ Discentes, Universidade Federal Rural de Pernambuco, UFRPE, Recife, PE, Brasil. E-mail: luciana-vilaca@hotmail.com; anidenechristina@yahoo.com.br

2 Pesquisador, UFRPE, Recife, PE, Brasil. E-mail: bete_zootec@hotmail.com

3 Profs., Unidade Acadêmica de Garanhuns, UFRPE-UAG, Garanhuns, PE, Brasil. E-mail: beteers@hotmail.com; krsantoro@, yahoo.com.br

4 Profs., UFRPE, Recife, PE, Brasil. E-mail: angelamvbatista@gmail.com; severino.pbarbosa@ufrpe.br

* Autor for correspondence
} 
Ma e $\mathrm{Mm}_{\text {cluster }}$ foram de 43,21 e 5,70\%, respectivamente. Em todos os grupos genéticos foram detectadas amostras positivas para Ma, enquanto que para $\mathrm{Mm}_{\text {cluster }}$ só foram observadas em animais das raças Moxotó, Parda Sertaneja e sem padrão racial definido. Observou-se diferença estatística $(p<0,05)$ entre as médias de proteína, caseína e CCS de amostras positivas e negativas para Ma. Para $\mathrm{Mm}_{\text {cluster }}$, verificou-se diferença estatística significativa apenas para o parâmetro CCS. A detecção de Mycoplasma em amostras de leite caprino sugere a introdução de animais infectados nos rebanhos avaliados, como também o possível contato com os agentes etiológicos em feiras e exposições.

Palavras-chave: Agalactia contagiosa. Caprinos leiteiros. Micoplasmose.

\section{Introduction}

Contagious agalactia of sheep and goats is a multiple etiology syndrome and is considered to be one of the most serious diseases in small ruminants (KUMAR et al., 2014). Included in the list of the mandatory notification diseases of the World Organisation for Animal Health (OIE), it is known to be responsible for high economic losses (SANTOS et al., 2015), and is characterized by the appearance of inflammatory lesions located in mammary gland, joints and eyes of the affected animals; this determines the classical triad of the disease: mastitis, arthritis and conjunctivitis (TODARO et al., 2015).

In goats, the disease is caused by Mycoplasma, a genus of bacteria which lacks cell walls. The species Mycoplasma agalactiae is responsible for $90 \%$ of the outbreaks in these animals and is the main etiological agent of contagious agalactia (KUMAR et al., 2014). However, in recent years, species belonging to the Mycoplasma mycoides cluster have also been appointed as etiological agents of the syndrome in goats (TATAY-DUALDE et al., 2017). This group consists of five species and subspecies of mycoplasmas that share many genotypic and phenotypic characteristics (WANG et al., 2014), including Mycoplasma mycoides subsp. capri and Mycoplasma capricolum subsp. capricolum (SANTOS et al., 2015).

In the northeastern region of Brazil, there have been reported occurrences of Mycoplasma agalactiae in herds located in the states of Paraíba (MORAES et al., 2017), Pernambuco (ALVES et al., 2013), Sergipe (SANTOS et al., 2015) and
Ceará (PEIXOTO et al., 2018). On the other hand, as far as we know, only Santos et al. (2018) have reported the occurrence of Mycoplasma mycoides cluster in that region.

Northeastern Brazil contains approximately 90\% of the country's goats; due to the economic losses that contagious agalactia may cause to livestock production in this region (SILVA et al., 2013), the diagnosis and identification of the species that cause this disease may reveal important information on the presence and circulation of these pathogens in goat herds and help to reduce the impacts caused by this disease on the production and quality of milk in addition to avoiding economic and public health problems.

Therefore, the present study aimed the detection of Mycoplasma agalactiae (Ma) and the Mycoplasma mycoides cluster $\left(\mathrm{Mm}_{\text {cluster }}\right)$, as well as to evaluate the composition and somatic cells count (SCC) in milk of positive goat from herds located in the states of Pernambuco and Paraíba, northeastern Brazil.

\section{Material and Methods}

\section{Animals and milk samples}

A total of 373 lactating female goats belonging to herds located in the states of Pernambuco (A, B, $\mathrm{C}$ and D) and Paraiba (E, F, G and H) were selected. The harvest period took place from July 2014 to July 2015. The breeding systems adopted in the herds were either of intensive (herds A, B and C), semi (herds E, F, G and H) or extensive (herd D) management types. 
The harvest of the milk samples was carried out after anti-septic treatment of the teats with $70 \%$ alcohol, followed by the disposal of the first jets. Individual samples were collected in sterile polypropylene containers, stored in isothermal boxes and sent to the laboratory.

\section{DNA extraction and amplification}

The extraction of DNA was performed by the method of silica/guanidine isothiocyanate, according to Boom et al. (1990). The quality of the extracted DNA was evaluated in 1\% agarose gel. The DNA was subjected to generic and speciesspecific PCR, using different pairs of primers and cycles. Initially, a multiplex-PCR was performed for the amplification of the genus Mycoplasma (MG F 5'- GGG AGC AAA CAG GAT TAG ATA CCC T - 3’; MG R 5' - TGC ACC ATC TGT CAC TCT GTT AAC CTC - 3') and selected internal markers (GAPDH F 5'- GGC AAG TTC CAT GGC ACA GT - 3'; GAPDH R 5'-GTC CCT CCA CGA TGC CAA $A G-3^{\prime}$ ), for evaluating the presence of possible PCR inhibitors and the integrity of the DNA samples.

The methodologies described by Kuppeveld et al. (1992) and Ravazzolo et al. (2006) were used for amplification of the genus (270 bp) and internal markers (125 bp), respectively. The reactions were performed in a final volume of $58 \mu 1$, composed of 5 $\mu \mathrm{L}$ of DNA, $45 \mu$ of the PCR Mix (Invitrogen, USA) and $2 \mu \mathrm{L}$ of each of the four primers described above. The conditions for amplification were as follows: initial denaturation for $5 \mathrm{~min}$ at $94{ }^{\circ} \mathrm{C}$, followed by 30 cycles of $1 \mathrm{~min}$ at $94{ }^{\circ} \mathrm{C}, 1 \mathrm{~min}$ at $58{ }^{\circ} \mathrm{C}$ and 1 min at $72{ }^{\circ} \mathrm{C}$, with a remaining final extension stage of $7 \mathrm{~min}$ at $72{ }^{\circ} \mathrm{C}$. All tests included both a positive and negative control (reaction without the presence of DNA).

For species-specific PCR, gene segments of 375 bp for Ma (F 5' - AAA GGT GCT TGA GAA ATG GC - 3'; R 5' - GTT GCA GAA GAA AGT CCA ATC A - 3') and 1500 bp for $\mathrm{Mm}_{\text {cluster }}$ (F 5' TAG AGG TAC TTT AGA TAC TCA AGG - 3';
R 5' - GAT ATC TAA AGG TGA TGG T- 3') were amplified, following methodologies described by Tola et al. (1997) and Bashiruddin et al. (1994), respectively. The species-specific PCR reactions were adjusted to a final volume of $58 \mu 1$, composed of $5 \mu \mathrm{l}$ of DNA, $45 \mu \mathrm{l}$ of PCR Mix (Invitrogen, USA) and $2 \mu 1$ of each primer described above. The amplification was performed under the following conditions: initial denaturation for $5 \mathrm{~min}$ at $94{ }^{\circ} \mathrm{C}$, followed by 30 cycles of $1 \mathrm{~min}$ at $94{ }^{\circ} \mathrm{C}, 1 \mathrm{~min}$ at $47^{\circ} \mathrm{C}$ for $\mathrm{Ma}$ or $50{ }^{\circ} \mathrm{C}$ for $\mathrm{Mm}_{\text {cluster }}$ and $1 \mathrm{~min}$ at 72 ${ }^{\circ} \mathrm{C}$, with a remaining final extension stage of $7 \mathrm{~min}$ at $72{ }^{\circ} \mathrm{C}$. Both positive (Mycoplasma agalactiae and Mycoplasma mycoides cluster) and negative (reaction without DNA) controls were included in all tests. PCR assay was performed in a DNA termal cycler (Mastercycler ${ }^{\circledR}$ Pro, Eppendorf, Germany) and the amplified PCR products were analyzed on a $1 \%$ agarose gel.

\section{Reproducibility test}

The reproducibility of the results was evaluated by amplification of 10 randomly selected DNA samples, amplified for three consecutive days under the same conditions cited above.

\section{Milk composition and SCC}

The analysis of the chemical composition of milk (protein, lactose, fat and casein) was determined by electronic methodologies based on medium infrared spectrometry, through Bentley 2000 equipment (Bentley Instruments Inc., USA). Somatic cell count (SCC) was obtained by flow cytometry in the electronic counter Somacount 300 (Bentley Instruments Inc, USA).

\section{Statistical analysis}

For the frequency analyses of amplicons and risk factors for the presence of Mycoplasma spp., the PROC FREQ procedure of the Statistical Analysis 
System version 9.1.3 (SAS Institute, Cary, NC, EUA) was used. To verify the effect of positivity for $\mathrm{Ma}$ and $\mathrm{Mm}_{\text {cluster }}$ on composition characteristics and SCC, analysis of variance and averages comparison tests were carried out using the PROC GLM procedure of the SAS 9.1.3.

\section{Results and Discussion}

In total, 360 DNA samples $(96.51 \%)$ were used for generic and species-specific PCR, according to the quality of the sample demonstrated by the amplification of the GAPDH constituent gene.

Table 1 shows the frequency of positivity for Mycoplasma spp., Ma and $\mathrm{Mm}_{\text {cluster }}$ The occurrence of the genus Mycoplasma was 46.42\% (169/360) in the evaluated herds; in the herds located in the state of Pernambuco, this ranged from 18.18 to $89.80 \%$ while for those located in the state of Paraíba, this ranged from 10.71 to $68.42 \%$. The presence of Mycoplasma spp. was also observed in small ruminants in Paraíba by Moraes et al. (2017).

Table 1. Absolute and relative frequency of positive milk samples for Mycoplasma spp., Mycoplasma agalactiae and the Mycoplasma mycoides cluster in goats belonging to herds in the states of Pernambuco and Paraíba, Brazil.

\begin{tabular}{cccccccc}
\hline & & \multicolumn{2}{c}{ Mycoplasma spp. } & \multicolumn{2}{c}{ Ma $_{\text {cluster }}$} \\
\cline { 3 - 8 } Herds & $\mathrm{n}$ & $\begin{array}{c}\text { Absolute } \\
\text { Freq. }\end{array}$ & $\begin{array}{c}\text { Relative } \\
\text { Freq. }\end{array}$ & $\begin{array}{c}\text { Absolute } \\
\text { Freq. }\end{array}$ & $\begin{array}{c}\text { Relative } \\
\text { Freq.* }\end{array}$ & $\begin{array}{c}\text { Absolute } \\
\text { Freq. }\end{array}$ & $\begin{array}{c}\text { Relative } \\
\text { Freq.* }\end{array}$ \\
\hline A & 47 & 19 & $40.43 \%$ & 15 & $78.95 \%$ & 3 & $15.78 \%$ \\
B & 49 & 44 & $89.80 \%$ & 44 & $100.0 \%$ & 0 & $0.00 \%$ \\
C & 25 & 14 & $56.00 \%$ & 14 & $100.0 \%$ & 0 & $0.00 \%$ \\
D & 33 & 6 & $18.18 \%$ & 4 & $66.67 \%$ & 0 & $0.00 \%$ \\
E & 60 & 33 & $55.00 \%$ & 32 & $96.97 \%$ & 17 & $51.51 \%$ \\
F & 38 & 26 & $68.42 \%$ & 25 & $96.15 \%$ & 0 & $0.00 \%$ \\
G & 52 & 16 & $30.77 \%$ & 15 & $93.75 \%$ & 1 & $6.25 \%$ \\
H & 56 & 6 & $10.71 \%$ & 5 & $83.33 \%$ & 0 & $0.00 \%$ \\
Total & 360 & 169 & $46.94 \%$ & 159 & $94.08 \%$ & 21 & $12.42 \%$ \\
\hline
\end{tabular}

$\mathrm{Ma}=$ Mycoplasma agalactiae $; \mathrm{M}_{\text {cluster }}=$ Mycoplasma mycoides cluster; *Relative frequency of positive samples for genus.

A high frequency in positive samples was found for Ma, totaling at $94.08 \%(159 / 169)$ of positive samples; this ranged from 66.67 to $100 \%$ in a given sampled herd. The frequency found for $\mathrm{Ma}$ in this study can be considered high when compared to the frequencies reported in other Brazilian states, such as 75\% in Pernambuco (ALVES et al., 2013), $10.3 \%$ in Sergipe (SANTOS et al., 2015) and $0.62 \%$ in Ceará (PEIXOTO et al., 2018).

The high frequency of Ma observed in this study confirms the largest incidence of the species and highlights it as the main etiological agent of contagious agalactia in the evaluated populations, emphasizing the importance of the detection of this microorganism and the need for more knowledge of sanitary conditions at the time of acquisition for new animals, so that it do not interfere with the sanitary conditions and productivity of existing animals (KUMAR et al., 2014). Care and attention to the health status of animals when are acquired is indispensable for all goat producers, but particularly for small one, since they often do not present financial resources to replace their herd or to implement disease control procedures; in these cases, the spread of the agent will entail greater damage (AZEVEDO et al., 2006). 
Unlike the observed for Ma, most of the samples (87.58\%) were negative for $\mathrm{Mm}_{\text {cluster }}$. As shown in Table 1, only herds A, E and G presented positive animals for that group of microorganisms, with frequencies of $15.78,51.51$ and $6.25 \%$ respectively. It should also be noted that two animals in herd A, sixteen in herd $\mathrm{E}$ and one animal in the herd $\mathrm{G}$ were simultaneously positive for $\mathrm{Ma}$ and $\mathrm{Mm}_{\text {cluster }}$.

The low occurrence of $\mathrm{Mm}_{\text {cluster }}$ observed in the studied herds suggests that the presence of a certain species of Mycoplasma may be related to the risk factors inherent to the animal and the type of management system, as suggested by Ariza-Miguel et al. (2012). In Brazil, most of the studies performed for the detection of species associated with the contagious agalactia reports the occurrence of Ma (AZEVEDO et al., 2015; PEIXOTO et al., 2018; SANTOS et al., 2015), with only a few assessments detecting the presence of $\mathrm{Mm}_{\text {cluster }}$ (SANTOS et al., 2018; BARBOSA et al., 2000).

The analysis of the risk factors "management system" and "racial pattern" were associated with the presence of the bacterium in the evaluated herds. In this assessment, it was observed that the type of management system has influence on the presence of the bacterium. According to Pereira et al. (2014), the practice of confining animals is a risk factor, since it exposes the animals to a greater number of infectious agents present in the accumulation of organic matter and humidity in such systems. In the present study, the semi-intensive and intensive type management systems were considered as a risk factor. The semi-intensive and intensive management systems presented by herds A, B, C, E, $\mathrm{F}, \mathrm{G}$ and $\mathrm{H}$ may have facilitated the dissemination of the etiological agent within the herds, a fact that can be corroborated by the high frequencies observed in these herds.
The frequency of positive animals for Mycoplasma spp., $\mathrm{Ma}$ and $\mathrm{Mm}_{\text {cluster }}$ by racial pattern is presented in Table 2. The occurrence of positive animals in all genetic groups is noted, with a greater frequency of Ma than other species. In terms of the genus Mycoplasma, it is noted that all genetic groups presented positive samples for this agent, with frequencies ranging from $12.70 \%$ in the Murcian breed to $77.42 \%$ in the Marota breed. The frequency of $\mathrm{Ma}$ in positive animals ranged from $87.5 \%$ in the Murcian breed to $100 \%$ of positive animals in the Anglo-Nubiana and Saanen breeds; at least one Ma positive animal was detected in each racial pattern. Positive samples for $\mathrm{Mm}_{\text {cluster }}$ were observed only in Moxotó (18.28\%) and Parda Sertaneja (1.92\%) breeds, and in animals with no defined breed pattern (SPRD) (3.12\%).

In this study, the racial pattern was also considered to be a risk factor for the presence of Mycoplasma spp. It is important to note that the largest frequencies found for the genus and for Ma specifically were verified in the animals of the Marota breed, and this fact could be related to the place of animal acquisition when composing the herd, since all the animals were originally brought from different regions of the country. It is known that these animals were obtained without the requirement of a negative certification for this bacterium by the breeders and without careful evaluation or quarantine before the introduction to the herd. In addition, these animals were subjected to a semi-intensive type management system, which probably allowed the spread within each herd. This is because the main reservoir of Mycoplasma spp. that cause contagious agalactia is an infected animal and the transmission can be carried out through direct contact with animals carrying the infectious agent in the oral cavity, respiratory tract and mammary glands (SANTOS et al., 2015). 
Table 2. Absolute and relative frequencies of positive milk samples for Mycoplasma spp., Mycoplasma agalactiae and the Mycoplasma mycoides cluster, according to the racial pattern of goats of herds in the states of Pernambuco and Paraíba, Brazil.

\begin{tabular}{cccccccc}
\hline \multirow{2}{*}{$\begin{array}{c}\text { Racial } \\
\text { pattern }\end{array}$} & $N$ & \multicolumn{2}{c}{ Mycoplasma spp. } & \multicolumn{2}{c}{ Ma } & \multicolumn{2}{c}{ Mm $_{\text {cluster }}$} \\
\cline { 3 - 8 } & & $\begin{array}{c}\text { Absolute } \\
\text { Freq. }\end{array}$ & $\begin{array}{c}\text { Relative } \\
\text { Freq. }\end{array}$ & $\begin{array}{c}\text { Absolute } \\
\text { Freq. }\end{array}$ & $\begin{array}{c}\text { Relative } \\
\text { Freq.* }\end{array}$ & $\begin{array}{c}\text { Absolute } \\
\text { Freq. }\end{array}$ & $\begin{array}{c}\text { Relative } \\
\text { Freq.* }\end{array}$ \\
\hline AN & 13 & 8 & $61.54 \%$ & 8 & $100.0 \%$ & 0 & $0.00 \%$ \\
Marota & 31 & 24 & $77.42 \%$ & 23 & $95.83 \%$ & 0 & $0.00 \%$ \\
Moxotó & 93 & 39 & $41.94 \%$ & 36 & $92.31 \%$ & 17 & $18.28 \%$ \\
Murciana & 63 & 8 & $12.70 \%$ & 7 & $87.50 \%$ & 0 & $0.00 \%$ \\
PS $^{3}$ & 52 & 16 & $30.77 \%$ & 15 & $93.75 \%$ & 1 & $1.92 \%$ \\
Saanen & 12 & 6 & $50.00 \%$ & 6 & $100.0 \%$ & 0 & $0.00 \%$ \\
SPRD $^{4}$ & 96 & 63 & $65.63 \%$ & 59 & $93.65 \%$ & 3 & $3.12 \%$ \\
Total & 360 & 169 & $46.94 \%$ & 159 & $94.08 \%$ & 21 & $12.42 \%$ \\
\hline
\end{tabular}

$\mathrm{Ma}=$ Mycoplasma agalactiae $; m_{\text {cluster }}=$ Mycoplasma mycoides cluster; $*$ Relative frequency of positive samples for genus; ${ }^{2}$ AngloNubiana; ${ }^{3}$ Parda Sertaneja; ${ }^{4}$ no defined breed pattern.

$\mathrm{Mm}_{\text {cluster }}$ was only detected in Moxotó and Parda Sertaneja breeds and in SPRD animals. The SPRD animals were acquired from other states and belonged to two distinct herds that carried out an exchange of animals between them, which may have facilitated the dissemination, as they also favored an intensive management system. The animals of the Parda Sertaneja breed had no contact with other races, but the introduction of $\mathrm{Mm}_{\text {cluster }}$ may possibly be related to the place of purchase of these animals or to participation in fairs.

The highest frequency of $\mathrm{Mm}_{\text {cluster }}$ was observed in the Moxoto race. It is important to note that milk samples of this breed were taken from two different herds ( $\mathrm{D}$ and $\mathrm{E}$ ), being all positive samples from herd E. This herd was kept in a semi-intensive management system, in which the animals were confined in close proximity during milking but were otherwise free to roam the Caatinga. The agent was possibly introduced into the herd from the purchase of infected animals and spread due to the proximity between infected and healthy animals, facilitated by the period of confinement during milking. On the other hand, the livestock of the herd D were created extensively, released in the Caatinga and possibly did not come into contact with animals carrying
$\mathrm{Mm}_{\text {cluster }}$. This information points out that the type of management employed is related to a greater or lesser incidence of the bacterium.

A significant practice in the acquisition of pathogens is the sending of animals to fairs and agricultural exhibitions. According to Bandeira et al. (2008) there is an association between Ma positivity and participation in dairy exhibitions and tournaments. It is noted that the animals of herds A, B, C, E, F, G and $\mathrm{H}$ periodically participated in these events, enabling contact with infected animals and facilitating the spread of microorganisms when they were reintroduced to the herd.

The herds $\mathrm{D}$ and $\mathrm{H}$ presented the smallest frequencies of Mycoplasma spp., Ma and $\mathrm{Mm}_{\text {cluster }}$. The smallest values obtained by the animals that composed herd D are possibly associated with their extensive breeding system. The presence of the infectious agent may be justified by the acquisition of animals from various localities when composing the herd, a practice observed in all herds evaluated in this study, which favors the introduction of the agent.

The comparison between the average values of composition and SCC parameters of the positive 
and negative samples for $\mathrm{Ma}$ and $\mathrm{Mm}_{\text {cluster }}$ are presented in Table 3. Statistical difference was observed by the Student's t-test $(\mathrm{p}<0.05)$ between the mean of protein, casein and SCC in positive and negative samples for Ma. For $\mathrm{Mm}_{\text {cluster }}$, significant statistical difference was only observed for the SCC parameter.

Table 3. Comparison between averages of fat, protein, lactose, total solids and SCC of goat milk samples positive and negative for Mycoplasma agalactie and the Mycoplasma mycoides cluster, belonging to herds in the states of Pernambuco and Paraíba, Brazil.

\begin{tabular}{cccc}
\hline & Variables & Positive & Negative \\
\hline \multirow{2}{*}{ Mycoplasma agalactiae } & Fat & $4.39^{\mathrm{A}}$ & $4.11^{\mathrm{A}}$ \\
& Protein & $3.67^{\mathrm{A}}$ & $3.46^{\mathrm{B}}$ \\
& Lactose & $4.19^{\mathrm{A}}$ & $4.30^{\mathrm{A}}$ \\
& Total solids & $13.19^{\mathrm{A}}$ & $12.78^{\mathrm{A}}$ \\
& Casein & $3.03^{\mathrm{A}}$ & $2.81^{\mathrm{B}}$ \\
& SCC (x1000) & $2,043.2^{\mathrm{A}}$ & $1,388.7^{\mathrm{B}}$ \\
& Fat & $4.24^{\mathrm{A}}$ & $4.20^{\mathrm{A}}$ \\
& Protein & $3.89^{\mathrm{A}}$ & $3.53^{\mathrm{A}}$ \\
& Lactose & $4.13^{\mathrm{A}}$ & $4.26^{\mathrm{A}}$ \\
& Total solids & $13.30^{\mathrm{A}}$ & $12.94^{\mathrm{A}}$ \\
& Casein & $3.23^{\mathrm{A}}$ & $2.89^{\mathrm{A}}$ \\
& SCC (x1000) & $2,803.4^{\mathrm{A}}$ & $1,606.7^{\mathrm{B}}$ \\
\hline
\end{tabular}

*Different letters on the same line indicate $\mathrm{p}<0.05$ by Student's t-test.

In this study the average values of total protein and casein were higher for positive samples when compared to negative samples for the infectious agent investigated. In the positive samples for Ma, the average total protein observed was $3.67 \%$. However, $16.35 \%(26 / 159)$ were below the required minimum of $2.8 \%$, recommended by current legislation. For casein, the average obtained for $\mathrm{Ma}$ positive samples was $3.03 \%$.

Mastitis is related to changes in the protein fractions present in the milk causing significant implications for the industrial yield (MA et al., 2000). This is because when suspended casein (micellar) precipitates, it gives rise to the process of coagulation in the manufacture of cheese (BRASIL et al., 2015). In this way, the higher the casein content, the greater the amount of cheese produced for each litre of milk.
Higher values were observed for total protein and casein in the milk samples positive for infectious agents in this study. However, as one of the main targets of contagious agalactia is the mammary gland (SILVA et al., 2013), affected animals may present a drastic decrease in their milk production but increase the concentration of total protein, as noted in this study. In such cases, the total protein is not a good indicator of productivity, since there is an increase in total protein values during the process of mammary gland infection, which is possibly associated with the increase of serum proteins in milk.

In this study the isolated effect of Mycoplasma spp. infection on the composition of goat milk was considered. However, it is known that goat milk composition can be influenced by multiple factors, such as: feeding, race, lactation period, milk 
production, season of the year, age of the animal (ALMEIDA et al., 2013), in addition to the presence of other microorganisms.

It was observed higher averages for SCC in relation to $\mathrm{Ma}$ and $\mathrm{Mm}_{\text {cluster }}$ positivity with values of $2,043.2 \times 10^{3}$ and $2,803.4 \times 10^{3}$ cells/ $\mathrm{mL}$, respectively. In the $\mathrm{Ma}$ and $\mathrm{Mm}_{\text {cluster }}$ positive samples, individual values above $1,000 \times 10^{3}$ cells/ $\mathrm{mL}$ were observed in $52.12(86 / 165)$ and $10.30 \%$ $(17 / 165)$ of these samples, respectively. SCC is an indicator of the sanitary status of the mammary gland and has been used as an indicator for udder health and microbiological quality in goats (PIRES et al., 2015). However, in goats, SCC should be used cautiously in the diagnosis of mastitis, since high concentrations of these cells are naturally found in goat milk (MADUREIRA et al., 2017; PIRES et al., 2015).

Despite the remarkable importance of SCC, the Normative Instruction No. 37 of the Ministry of Agriculture, Livestock, and Food Supply (MAPA) does not set a limit for this parameter (BRASIL, 2000), although several studies indicate the limit of $1,000 \times 10^{3}$ cells $/ \mathrm{mL}$ as indicative of intramammary infection (SOUZA et al., 2012). In the present study the SCC averages of positive samples for Ma and $\mathrm{Mm}_{\text {cluster }}$ were higher than this value. Significant increases in SCC were related to the presence of Mycoplasma spp. by other authors (AL-FARHA et al., 2017).

The results of this study suggest that the creation of a national sanitary program aimed at preventing the introduction and dissemination of mycoplasmas in different regions of Brazil is necessary. In this sense, it becomes a matter of urgency to facilitate the access of goat producers to efficient techniques for the early detection of the main species of this agent, in order to avoid dissemination and to enable more effective control within and between the herds, reducing economic losses.

\section{Acknowledgments}

We would like to thank CAPES for grant of the scholarship, National Council for Scientific and Technological Development (CNPq) and FACEPE (Fundação de Apoio a Pesquisa do estado de Pernambuco) for funding this study.

\section{References}

AL-FARHA, A. A. B.; HEMMATZADEH, F.; KHAZANDI, M.; HOARE, A.; PETROVSKI, K. Evaluation of effects of Mycoplasma mastitis on milk composition in dairy cattle from South Australia. BMC Veterinary Research, v. 13, n. 351, p. 1-8, 2017. DOI: 10.1186/S1291701712742.

ALMEIDA, J. F.; AQUINO, M. H. C.; MAGALHÃES, H.; NASCIMENTO, E. R.; PEREIRA, V. L. A.; FERREIRA, T., BARRETO, M. L. Principais alterações no leite por agentes causadores de mastite no rebanho caprino dos estados de Minas Gerais e Rio de Janeiro. Arquivos do Instituto Biológico, v. 80, n. 1, p. 13-18, 2013. DOI: $10.1590 / \mathrm{S} 180816572013000100003$.

ALVES, B. H. L. S.; SILVA, J. G.; MOTA A. R; CAMPOS A. C.; JÚNIOR, J. W. P.; SANTOS, S. B.; MOTA, R. A. Mycoplasma agalactiae in semen and milk of goat from Pernambuco State, Brazil. Pesquisa Veterinária Brasileira, v. 33, n. 11, p. 1309-1312, 2013. DOI: 10.1590/S0100736X2013001100004.

ARIZA-MIGUEL，J.; RODRÍGUEZ-LÁZARO, D.; HERNÁNDEZ, M. A survey of Mycoplasma agalactiae in dairy sheep farms in Spain. BMC Veterinary Research, v. 8 , n. 1, p. 1-6, 2012. DOI: 10.1186/174661488171.

AZEVEDO, E. O.; CÂMARA, D. R.; SILVA, S. V.; GUERRA, M. M. P. Agalaxia contagiosa: Um "novo" problema para caprinos e ovinos no Brasil. Ciência Veterinária nos Trópicos, v. 18, n. 2, p. 34-38, 2015.

AZEVEDO, E. O.; ALCÂNTARA, M. D. B.; NASCIMENTO, E. R.; TABOSA, I. M.; BARRETO, M. L.; ALMEIDA, J. F. DE; ARAÚJO, M. D.; RODRIGUES, A. R. O.; RIET-CORREA, F.; CASTRO, R. S. de. Contagious agalactia by Mycoplasma Agalactia in small ruminants in Brazil: first report. Brazilian Journal of Microbiology, v. 37, n. 4, p. 576-581, 2006. DOI: $10.1590 / \mathrm{S} 151783822006000400033$.

BANDEIRA, D. A.; CASTRO, R. S.; AZEVEDO, E. O.; NASCIMENTO, E. R.; MELO, L. S. S.; MELO, C. B. Infection by Mycoplasma agalactiae in dairy goat herds in the microregions of Cariri in Paraíba State, Brazil. Arquivo Brasileiro de Medicina Veterinária e 
Zootecnia, v. 60, n. 5, p. 1255-1258, 2008. DOI: $10.1590 /$ S010209352008000500031.

BARBOSA, V. P.; NASCIMENTO, E. R.; DANELLI, M. G. M.; NASCIMENTO, M. G. F.; SANTOS, M. A. J.; LIGNON, G. B.; RIBEIRO, V. R. Diferenciação de tipos de Mycoplasma mycoides na etiopatogenia da micoplasmose caprina. Revista Brasileira de Medicina Veterinária, v. 7, n. 1, p. 33-36, 2000. DOI: 10.4322/ rbcv.2015.172.

BASHIRUDDIN, J. B.; TAYLOR, T. K.; GOULD, A. R. A PCR-based test for the specific identification of Mycoplasma mycoides subspecies mycoides SC. Journal of Veterinary Diagnostic Investigation, v. 6, n. 4, p. 428434, 1994. DOI: 10.1177/104063879400600405.

BOOM, R., SOL, C. J.; SALIMANS, M. M.; JANSEN, C. L.; WERTHEIM-VAN, D. P. M.; NOORDAA, V. J. Rapid and simple method for purification of nucleic acids. Journal of Clinical Microbiology, v. 28, n. 3, p. 495-503, 1990

BRASIL, MINISTÉRIO DA AGRICULTURA E DO ABASTECIMENTO. Secretaria de Defesa Agropecuária. Regulamento técnico de produção, identidade e qualidade do leite de cabra. Instrução Normativa $n^{\circ} 37$ de 31 de outubro de 2000. Diário Oficial [da] União, Brasília, 8 nov. 2000.

BRASIL, R. B.; NICOLA, E. S.; CABRAL, J. F.; SILVA, M. A. P. Estrutura e estabilidade das micelas de caseína do leite bovino. Ciência Animal, v. 25, n. 2, p. 71-80, 2015.

KUMAR, A.; RAHAL, A.; CHAKRABORTY, S.; VERMA, A. K.; DHAMA, K. Mycoplasma agalactiae an etiological agent of contagious agalactia in small ruminants: a review. Veterinary Medicine International, v. 2014, n. 2014, p. 1-13, 2014. DOI: 10.1155/2014/286752

KUPPEVELD, F. J. V.; LOGT, J. T. V. D.; ANGULO, A. F.; ZOEST, M. J. V.; QUINT, W. G.; NIESTERS, H. G.; GALAMA, J. M.; MELCHERS, W. J. Genus and species-specific identification of Mycoplasmas by 16S rRNA amplification. Applied and Environmental Microbiology, v. 52, n. 8, p. 2606-2615, 1992.

MA, Y.; RYAN, C.; BARBANO, D. M.; GALTON, D. M.; RUDAN, M. A.; BOOR, K. J. Effects of somatic cell count on quality and shelf-life of pasteurized fluid milk. Journal of Dairy Science, v. 83, n. 1, p. 1-11, 2000. DOI: 10.1590/s151999402018000400004.

MADUREIRA, K. M.; GOMES, V.; ARAÚJO, W. P. Características físico-químicas e celulares do leite de cabras Saanen, Alpina e Toggenburg. Revista Brasileira de Ciência Veterinária, v. 24, n. 1, p. 39-43, 2017. DOI: 10.4322/rbcv.2017.008.
MORAES, A. G. M.; CORDEIRO, A. A.; SILVA, N. S.; CAMPOS, A. C.; MELO, M. A.; AZEVEDO, E. O. Isolamento de Mycoplasma spp. no trato reprodutivo de pequenos ruminantes no semiárido paraibano. Archives of Veterinary Science, v. 22, p. 18-22, 2017. DOI: 10.5380/ avs.v22i2.39858.

PEIXOTO, R. M.; ANDRIOLI, A.; PINHEIRO, R. R.; ALVES, F. S. F.; SANTOS, V. W. S. dos; SOUSA, M. M. de; AZEVEDO, D. A. A. de; DAMASCENO, E. M.; TEIXEIRA, M. F. S. Mycoplasma agalactiae em rebanhos leiteiros no estado do Ceará em associação com o vírus da artrite encefalite caprina. Acta Scientiae Veterinariae, v. 46, n. 1533, p. 1-6, 2018. DOI: $10.22456 / 1679-9216.81885$

PEREIRA, P. F. V. Fatores de risco, etiologia e aspectos clínicos da mastite em ovelhas de corte no Paraná. Pesquisa Veterinária Brasileira, v. 34, n. 1, p. 1-10, 2014. DOI: $10.1590 / \mathrm{S} 0100-736 \mathrm{X} 2014000100001$

PIRES, A.; SOBRAL, P.; GOMES, A.; PARDAL, P. Qualidade higiénica do leite de caprinos da raça serrana, ecótipo ribatejano, explorados na região do Ribatejo e Oeste. Revista da Unidade de Investigação do Instituto Politécnico de Santarém, v. 3, n. 4, p. 192-215, 2015. DOI: $10.25746 /$ ruiips.v3.i4.14375

RAVAZZOLO, A. P.; NENCI, C.; VOGT, H. R.; WALDVOGEL, A.; OBEXER-RUFF, G.; PETERHANS, E.; BERTONI, G. Viral load, organ distribution, histopathological lesions, and cytokine mRNA expression in goats infected with a molecular clone of the caprine arthritis encephalitis virus. Virology Journal, v. 350, n. 1, p. 116-127, 2006. DOI: 10.1016/j.virol.2006.02.014

SANTOS, O. M.; CAMPOS, A. C.; SANTOS, J. P.; SANTOS, P. O. M.; CALDAS, E. L. C.; SANTOS, A. D. F.; NASCIMENTO, E. R.; CASTRO, R. S.; AZEVEDO, E. O. Agalaxia contagiosa em ovinos e caprinos do Estado do Sergipe: dados preliminares. Scientia Plena, v. 11, n. 4, p. 1-5, 2015.

SANTOS, S. B. dos; MELO, R. P. B.; SILVA, L. T. R.; OLIVEIRA, J. M. B.; ABAD, A. C. A.; PNHEIRO JÚNIOR, J. W.; MOTA, R. A. Epidemiology of Mycoplasma agalactiae and Mycoplasma mycoides cluster in flocks of northeastern Brazil. Ciência Rural, v. 48, n. 4, 2018. DOI: 10.1590/0103-8478cr20170427

SAS Institute Inc. 2002-2003. Statistical analysis system. Release 9.1.3 (Software). Cary. EUA

SILVA, N. S.; MARINHO, M. L., AZEVEDO, E. O.; CAMPOS, A. C.; CARVALHO, M. G. X. Tratamento alopático e homeopático em caprinos com agalaxia contagiosa: estudo comparativo. Archives of Veterinary Science, v. 18 , n. 4 , p. $57-64$, 2013. DOI: $10.5380 /$ avs. v18i4.31114 
SOUZA, F. N.; BLAGITZ, M. G.; PENNA, C. F. A. M.; DELLA LIBERA, A. M. M. P.; HEINEMANN, M. B.; CERQUEIRA, M. M. O. P. Somatic cell count in small ruminants: friend or foe? Small Ruminant Research, v. 107 , n. 4, p. $65-75$, 2012. DOI: $10.1016 /$ j. smallrumres.2012.04.005

TATAY-DUALDE, J.; HAM, M. P. D.; PATERNA, C. F. A.; SÁNCHEZ, A.; CORRALES, J. C.; CONTRERAS, A.; TOLA, S.; GÓMEZ-MARTIN, Á. Antimicrobial susceptibility and multilocus sequence typing of Mycoplasma capricolum subsp. capricolum. PLoS ONE, v. 12, n. 3, 2017. DOI: 10.1371/journal.pone. 0174700

TODARO, M.; PULEIO, R.; SABELLI, C.; SCATASSA, M. L.; CONSOLE, A.; LORIA, G. R. Determination of milk production losses in Valle del Belice sheep following experimental infection of Mycoplasma agalactiae. Small Ruminant Research, v. 123, n. 1, p. 167-172, 2015. DOI: 10.1016/j.smallrumres.2014.10.005

TOLA, S.; ANGIOI, A.; ROCCHIGIANI, A. M.; IDINI, G.; MANUNTA, D.; GALLERI, G.; LEORI, G. Detection of Mycoplasma agalactiae in sheep milk samples by polymerase chain reaction. Veterinary Microbiology, v. 54, n. 1, p. 17-22, 1997. DOI: 10.1016/ S0378-1135(96)01269-2

WANG, H.; NI, L.; YANG, H.; XU, L.; MA, N.; DING, H. Isolation and identification of Mycoplasma mycoides cluster strains from goats in Chongqing, China. Bulletin of the Veterinary Institute in Pulawy, v. 58, n. 1, p. 11-15, 2014. DOI: 10.2478/bvip-2014-0002 